\title{
A Second Step to Mathematical Olympiad Problems
}


This page intentionally left blank 


\section{Derek Holton}

University of Otago, New Zealand \& University of Melbourne, Australia

\section{Vol. 7 Mathematical \\ Series}

\section{A Second Step to Mathematical Olympiad Problems}




\section{Published by}

World Scientific Publishing Co. Pte. Ltd.

5 Toh Tuck Link, Singapore 596224

USA office: 27 Warren Street, Suite 401-402, Hackensack, NJ 07601

UK office: 57 Shelton Street, Covent Garden, London WC2H 9HE

\section{British Library Cataloguing-in-Publication Data}

A catalogue record for this book is available from the British Library.

\section{Mathematical Olympiad Series - Vol. 7 \\ A SECOND STEP TO MATHEMATICAL OLYMPIAD PROBLEMS}

Copyright (c) 2011 by World Scientific Publishing Co. Pte. Ltd.

All rights reserved. This book, or parts thereof, may not be reproduced in any form or by any means, electronic or mechanical, including photocopying, recording or any information storage and retrieval system now known or to be invented, without written permission from the Publisher.

For photocopying of material in this volume, please pay a copying fee through the Copyright Clearance Center, Inc., 222 Rosewood Drive, Danvers, MA 01923, USA. In this case permission to photocopy is not required from the publisher.

ISBN-13 978-981-4327-87-9 (pbk)

ISBN-10 981-4327-87-5 (pbk)

Typeset by Stallion Press

Email: enquiries@stallionpress.com

Printed in Singapore. 
To Lee Peng Yee, a true friend and all-round nice guy, who was instrumental in finding a publisher for both Steps. 
This page intentionally left blank 


\section{Foreword}

This is the second of two volumes on some higher level problem solving and largely contains material that is not taught in most Western schools. Like the first volume (A First Step to Mathematical Olympiad Problems), most of the content here was developed initially as an aid for New Zealand students who were hoping to get to an International Mathematical Olympiad (IMO). This original material was presented in the form of 15 yellow booklets. The first eight of these are the basis of First Step; the remaining seven underpin this volume. However, it should be noted that there are also new pieces here. The whole of Chapter 3 was not in the initial yellow booklets neither were many sections and problems that are dotted around the rest of the book.

This book should help improve the background of students preparing for regional and national mathematics competitions by providing them with theorems, ideas and techniques that they may not have already met. It will also give them suggestions on how to approach problems that they have not seen before. But the step to the IMO from regional and national competitions is likely to be a big one and the First and Second Steps should not be considered as a total preparation for an IMO. Hopefully though, they are good stepping stones along the way.

But I hope that the book will also be read by both students and teachers who are interested in mathematics. There are sufficiently many problems here to while away many happy and frustrating hours. I hope that this book encourages many readers to simply enjoy mathematics for its own sake and for the pleasure of getting a problem out.

Finally I would like to thank Irene Goodwin (who is now, unfortunately, no longer with us), Lenette Grant and Leanne Kirk for their help to me while the yellow booklets were being prepared and in the many years since, and to Zhang Ji for her work in turning yellow booklets into Steps. 
This page intentionally left blank 


\section{Contents}

Foreword vii

1. Combinatorics 1

1.1. A Quick Reminder . . . . . . . . . . . . . . . . 1

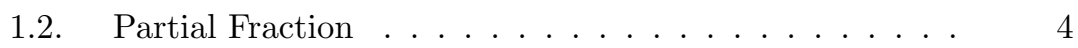

1.3. Geometric Progressions . . . . . . . . . . . . . . . 9

1.4. Extending the Binomial Theorem . . . . . . . . . . 12

1.5. Recurrence Relations . . . . . . . . . . . . . . . . . 14

1.6. Generating Functions . . . . . . . . . . . . . 20

1.7. Of Rabbits and Postmen .............. 24

1.8. Solutions .................... 29

2. Geometry $3 \quad 41$

2.1. The Circumcircle . . . . . . . . . . . . . 42

2.2. Incircles . . . . . . . . . . . . . . . . . . . . 46

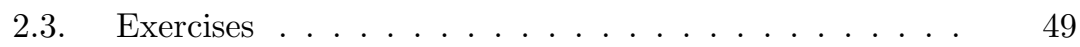

2.4. The 6 -Point Circle? . . . . . . . . . . . . . 51

2.5. The Euler Line and the Nine Point Circle . . . . . . . . . 56

2.6. Some More Examples . . . . . . . . . . . . . . . . 58

2.7. Hints . . . . . . . . . . . . . . . 60

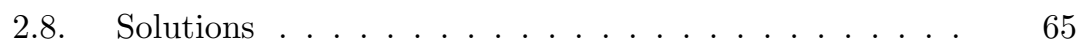

2.9. Glossary ..................... 84

3. Solving Problems $\quad 85$

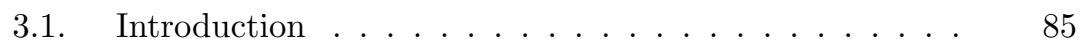

3.2. A Problem to Solve ................... 85

3.3. Mathematics: What is it? . . . . . . . . . . . . 87

3.4. Back to Six Circles . . . . . . . . . . . . . . 90

3.5. More on Research Methods . . . . . . . . . . . . . . 91

3.6. Georg Pólya . . . . . . . . . . . . . . . 98 
3.7. Asking Questions . . . . . . . . . . . . . . . 100

3.8. Solutions . . . . . . . . . . . . . . . . 102

4. Number Theory $2 \quad 107$

4.1. A Problem ................... 107

4.2. Euler's $\phi$-function . . . . . . . . . . . . . . 110

4.3. Back to Section $4.2 \ldots \ldots \ldots \ldots \ldots$

4.4. Wilson ................... 115

4.5. Some More Problems . . . . . . . . . . . . . . . . 117

4.6. Solutions . . . . . . . . . . . . . . . . 118

5. Means and Inequalities 133

5.1. Introduction . . . . . . . . . . . . . . 133

5.2. Rules to Order the Reals By . . . . . . . . . . . 133

5.3. Means Arithmetic and Geometric ... . . . . . . 135

5.4. More Means . . . . . . . . . . . . . . . . . . . . 139

5.5. More Inequalities . . . . . . . . . . . . . . . . 141

5.6. A Collection of Problems . . . . . . . . . . . . 146

5.7. Solutions . . . . . . . . . . . . . . . . . 148

$\begin{array}{lll}\text { 6. } & \text { Combinatorics } 3 & 167\end{array}$

6.1. Introduction . . . . . . . . . . . . . 167

6.2. Inclusion-Exclusion . . . . . . . . . . . . . . 167

6.3. Derangements (Revisited) . . . . . . . . . . . . . 172

6.4. Linear Diophantine Equations Again . . . . . . . . . 174

6.5. Non-taking Rooks . . . . . . . . . . . . . . . . 176

6.6. The Board of Forbidden Positions . . . . . . . . . . . 183

6.7. Stirling Numbers . . . . . . . . . . . . . . . . 187

6.8. Some Other Numbers . . . . . . . . . . . . . . . . 190

6.9. Solutions .................... 195

7. Creating Problems 215

7.1. Introduction . . . . . . . . . . . . . . 215

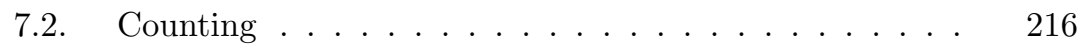

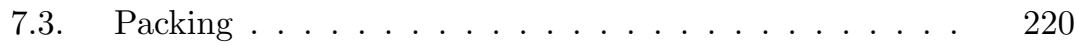

7.4. Intersecting . . . . . . . . . . . . . . . 224

7.5. Chessboards .................. 230

7.6. Squigonometry ................. 233 
7.7. The Equations of Squares . . . . . . . . . . . 236

7.8. Solutions . . . . . . . . . . . . . . . 238

8. IMO Problems $2 \quad 257$

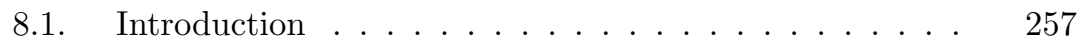

8.2 AUS $3 \ldots \ldots \ldots \ldots \ldots \ldots \ldots \ldots$

8.3. HEL $2 \ldots \ldots \ldots \ldots \ldots \ldots \ldots \ldots$

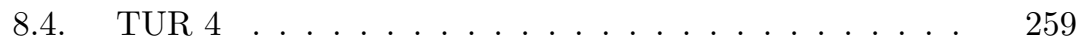

8.5. ROM $4 \ldots \ldots \ldots \ldots \ldots \ldots \ldots$

8.6. USS $1 \ldots \ldots \ldots \ldots \ldots \ldots \ldots$

8.7. Revue ...................... 260

8.8. Hints - AUS $3 \ldots \ldots \ldots \ldots$

8.9. Hints - HEL $2 \ldots \ldots \ldots \ldots$

8.10. Hints - TUR $4 \ldots \ldots \ldots \ldots \ldots$

8.11. Hints - ROM $4 \ldots \ldots \ldots \ldots$

8.12. Hints - USS $1 \ldots \ldots \ldots \ldots$. . . . . . . . 268

8.13. Some More Olympiad Problems . . . . . . . . . . 269

8.14. Solutions . . . . . . . . . . . . . . . . 272

$\begin{array}{ll}\text { Index } & 295\end{array}$ 